\title{
Gejala Gastrointestinal sebagai Faktor Prognostik Keparahan dan Kematian pada Pasien COVID-19: Sebuah Meta-Analisis Global
}

\author{
Taufik Ridwan Hadi Kusuma ${ }^{*}$, Mentari Maratus Sholihah ${ }^{1}$, \\ Muhammad Ifham Hanif ${ }^{2}$ \\ 1.Fakultas Kedokteran, Universitas Sebelas Maret, Surakarta \\ 2.RSUP Dr. Hasan Sadikin, Fakultas Kedokteran, Universitas Padjadjaran, Bandung \\ Korespondensi : taufik.ridwan.hk@student.uns.ac.id
}

\begin{abstract}
ABSTRAK
Pendahuluan: Coronavirus disease 2019 (COVID-19) merupakan pandemi global yang menimbulkan manifestasi klinis yang luas termasuk gejala gastrointestinal. Beberapa studi telah meneliti tingkat keparahan dan mortalitas COVID-19 dengan manifestasi gastrointestinal, tetapi hanya di tingkat regional. Penelitian ini bertujuan untuk menggabungkan beberapa literatur tentang keparahan dan mortalitas akibat COVID-19 dengan manifestasi gastrointestinal di beberapa pusat studi dari berbagai negara.

Metode: Studi ini merupakan studi meta-analisis. Penelitian ini dilakukan dengan menggunakan data sekunder yang diperoleh dari proses pencarian dan pemilihan data dari studi klinis di seluruh dunia. Pencarian artikel melalui database yang sistematik dan komprehensif dari PubMed, ScienceDirect, Google Scholar, ProQuest, dan Springer Link. Artikel dikumpulkan dengan diagram PRISMA, dilakukan telaah kritis menggunakan PRISMA checklist dan analisis PICO kemudian data dianalisis dengan menggunakan perangkat Review Manager 5.4.1 dengan Random Effect Model (REM). Hasil analisis yang didapatkan berupa besarnya efek, heterogenitas dan model studi.

Hasil: Berdasarkan analisis data dari berbagai studi di beberapa negara, hasil menunjukkan bahwa gejala gastrointestinal tidak memiliki hubungan signifikan terhadap peningkatan keparahan (aOR $0.77 ; 95 \%$ CI $0.35-1.70 ; \mathrm{I}^{2}=0.73 ; \mathrm{p}=0.52$ ) dan mortalitas (aOR 0.87; 95\% CI 0.34-2.21; $\mathrm{I}^{2}=0.63 ; \mathrm{p}=0.77$ ) COVID-19.

Kesimpulan: Pasien COVID-19 dengan gejala gastrointestinal lebih kecil kemungkinannya untuk mengalami penyakit yang parah serta mortalitas dibandingkan pasien tanpa gejala gastrointestinal.
\end{abstract}

Kata Kunci: Gejala Gastrointestinal; COVID-19; Faktor Prognosis; Keparahan; Kematian

\section{ABSTRACT}

Introduction: Coronavirus disease 2019 (COVID-19) is a global pandemic that causes a wide range of clinical manifestations, including gastrointestinal symptoms. Several studies have examined the severity and mortality of COVID-19 with gastrointestinal manifestations, but only at the regional level. This study aims to combine several literatures on severity and mortality due to COVID-19 with gastrointestinal manifestations in multiple centers of studies in various countries.

Methods: This study is a meta-analysis. The research was conducted using secondary data by searching and selecting data from clinical studies worldwide. The article searching was through a systematic and comprehensive database from PubMed, ScienceDirect, Google Scholar, ProQuest, and Springer Link. Articles were collected using the PRISMA diagram, critically appraised using the PRISMA checklist and PICO analysis, then the data were analyzed using Review Manager 5.4.1 application with 
Random Effect Model (REM). The results of the analysis are the effect size, heterogeneity, and the study model.

Results: Based on the data analysis from various studies in multiple countries, the results showed that the gastrointestinal symptoms did not have a significant correlation with increased severity (aOR 0.77; 95\% CI 0.35-1.70; $\left.I^{2}=0.73 ; p=0.52\right)$ and mortality (aOR $0.87 ; 95 \%$ CI 0.34-2.21; $\left.I^{2}=0.63 ; p=0.77\right)$ of COVID -19 .

Conclusion: COVID-19 patients with gastrointestinal symptoms were less likely to have severe disease and mortality than patients without gastrointestinal symptoms

Keywords: Gastrointestinal Symptoms; COVID-19; Prognostic Factor; Severity; Mortality

\section{PENDAHULUAN}

Coronavirus Disease 2019 (COVID19) adalah pandemi global yang pertama kali muncul di Wuhan (Hubei, China). Organisasi Kesehatan Dunia (WHO) menyatakan COVID-19 sebagai keadaan darurat dan ancaman global ${ }^{1}$. Secara global, menurut laporan mingguan Organisasi Kesehatan Dunia (WHO) tertanggal 25 Mei 2021, terdapat lebih dari 4,1 juta kasus baru dan 84.000 kematian baru dilaporkan. Beberapa wilayah seperti Amerika, Mediterania Timur, Afrika, dan Wilayah Pasifik Barat semuanya masih melaporkan jumlah kasus baru yang sama dengan minggu sebelumnya. Sementara itu, Eropa melaporkan penurunan paling signifikan dalam kasus baru minggu ini, diikuti oleh Asia Tenggara ${ }^{2}$.

COVID-19 disebabkan oleh Severe Acute Respiratory Syndrome Coronavirus-2 (SARS-CoV-2), yang memiliki manifestasi utama seperti demam, batuk kering, sakit tenggorokan, hidung tersumbat, kehilangan indra penciuman, sakit kepala, dan sesak napas (3). Di seluruh dunia, COVID-19 merupakan masalah serius, karena kasus COVID-19 yang parah dapat menyebabkan berbagai komplikasi pada organ tubuh, seperti gangguan ginjal, jantung, saraf, hati, bahkan gangguan multi organ yang berujung pada kematian ${ }^{4}$. Namun penelitian tentang manifestasi gastrointestinal (GI) COVID-19, seperti mual, muntah, diare, dan sakit perut, baru-baru ini menjadi perhatian yang signifikan ${ }^{5}$.
SARS-CoV-2 mengikat AngiotensinConverting Enzyme 2 (ACE2), yang merupakan reseptor seluler, dengan bantuan envelope spike protein (S protein). Selain itu, ekspresi ACE2 tertinggi pada sel epitel usus terutama pada enterosit proksimal dan distal. Mekanisme ini berkontribusi terhadap terjadinya manifestasi gastrointestinal ${ }^{5}$.

Beberapa studi sebelumnya telah meneliti tingkat keparahan dan kematian COVID-19 dengan manifestasi gastrointestinal ${ }^{6-11}$. Studi meta-analisis ini menggabungkan beberapa literatur tentang tingkat keparahan dan kematian akibat COVID-19 dengan gejala gastrointestinal di banyak negara.

\section{METODE}

\section{Desain Penelitian}

Penelitian ini merupakan telaah sistematis dan meta-analisis. Penelitian ini menggunakan data yang dikumpulkan melalui database PubMed, ScienceDirect, Google Scholar, ProQuest dan SpringerLink menggunakan kata kunci (Gastrointestinal symptoms OR gastrointestinal manifestation) AND (mortality OR severity) AND (COVID19 OR Coronavirus OR SARS-CoV-2). Studistudi yang didokumentasikan menggunakan panduan PRISMA. Setelah itu dilakukan telaah kritis oleh ketiga penulis menggunakan Quality Assessment Tools for Observational Cohort and Cross-Sectional Studies NIH (National Institutes of Health) dan analisis PICO, kemudian data dianalisis menggunakan Review Manager 5.4.1 (RevMan 5.4.1) 
dengan Random Effect Model (REM). Hasil yang didapatkan meliputi effect size, heterogenitas dan model studi.

\section{Kriteria Inklusi}

Artikel yang masuk ke dalam kriteria inklusi dalam studi ini yaitu yang dipublikasikan selama tahun 2020 dan 2021, termasuk studi observasional (retrospektif maupun prospektif) yang berupa studi primer dilakukan di rumah sakit. Pasien dewasa yang terdiagnosa COVID-19 digunakan sebagai subjek penelitian. Hanya artikel dalam bahasa inggris yang di inklusikan. Artikel-artikel tersebut merupakan artikel yang membahas dampak gejala GI terhadap keparahan dan kematian pasien COVID-19.

\section{Kriteria Eksklusi}

Studi ini mengeksklusikan artikelartikel dengan desain penelitian randomized control trial, quasi-experimental, casecontrol, artikel yang tidak dipublikasikan dalam bahasa inggris, serta penelitian yang melibatkan pasien pediatri dan wanita hamil.

\section{Definisi Operasional Variabel}

Gejala gastrointestinal didefinisikan sebagai diare, mual, muntah dan nyeri abdomen atau campuran beberapa gejala. Kematian pasien COVID-19 didefinisikan ketika terjadi henti fungsi jantung, sirkulasi dan pernafasan secara permanen. Outcome yang dinilai disini yaitu meninggal atau tidak. Tingkat keparahan penyakit yang dimaksud dalam studi ini yaitu ketika pasien memerlukan perawatan ICU, termasuk didalamnya membutuhkan ventilasi mekanis.

\section{Instrumen Penelitian}

Instrumen penelitian yang digunakan yaitu artikel mengenai pengaruh gejala GI terhadap keparahan dan kematian pada pasien COVID-19 yang telah dipublikasikan. Artikel-artikel tersebut dipublikasikan selama tahun 2020-2021 yang diperoleh melalui pencarian yang sistematik dan komprehensif dalam database PubMed, ScienceDirect, Google Scholar, ProQuest dan Springer Link.

\section{Analisis Data}

Analisis data dalam studi ini menggunakan RevMan 5.4.1. Analisis menghasilkan tiga output: ukuran efek, heterogenitas dan model studi dengan Random Effect Model (REM).

\section{HASIL}

Proses pencarian awal melalui database menghasilkan 972 artikel. Setelah menghilangkan artikel duplikat, 957 artikel dieksklusikan dengan alasan berikut: artikel yang tidak relevan $(\mathrm{n}=340)$ artikel tanpa full text $(\mathrm{n}=145)$, randomized controlled trials $(\mathrm{n}=8)$, meta analisis $(\mathrm{n}=37)$, systematic review $(\mathrm{n}=61)$, case control $(\mathrm{n}=186)$, artikel dengan subjek penelitian pediatri $(\mathrm{n}=158)$ dan penelitian pada wanita hamil $(\mathrm{n}=22)$. Tiga belas artikel full text dinilai untuk kelayakan, kemudian 6 artikel dieksklusikan karena outcome penelitian bukan kematian atau keparahan. Total 7 studi didapatkan memenuhi kriteria inklusi. 


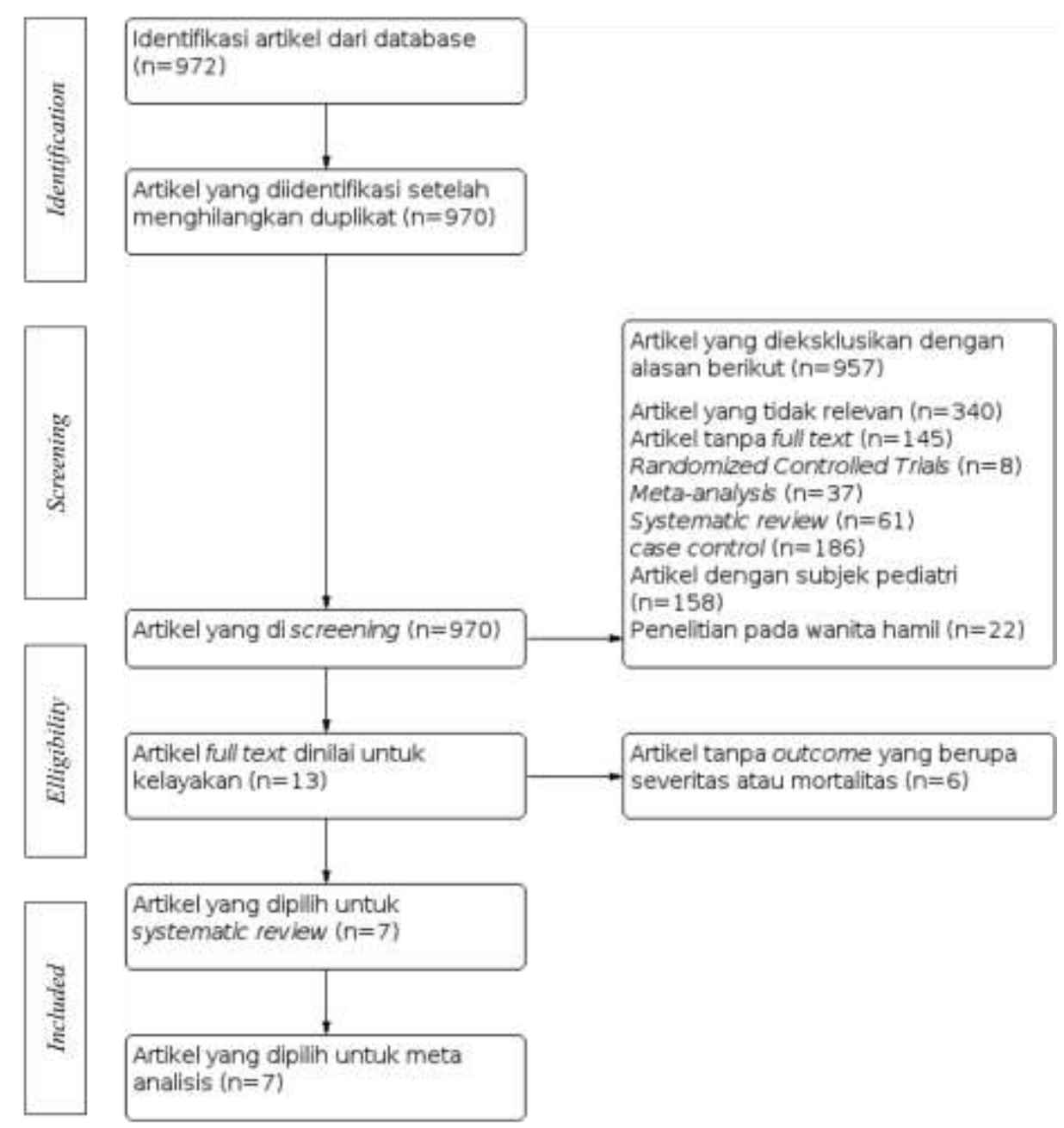

Gambar 1. Diagram PRISMA

Studi yang masuk kriteria inklusi kemudian dinilai kualitasnya secara kuantitatif dan kualitatif. Penilaian kualitas dalam penelitian ini dilakukan dengan menggunakan Quality Assessment Tools for Observational Cohort dan Cross-Sectional Studies yang diterbitkan oleh NIH (National Institutes of Health).

Kriteria penilaian ini menggunakan skor dari empat belas kriteria, dengan masingmasing kriteria diberi skor 1 jika menjawab ya dan diberi skor 0 jika menjawab tidak. Penelitian dikategorikan berkualitas baik jika skor 8, skor kualitas cukup 6-7, dan kualitas kurang <6. Enam artikel yang masuk kriteria inklusi dalam penelitian ini memiliki kualitas yang baik, dan satu artikel memiliki kualitas cukup.

\section{Karakteristik Penelitian yang Digunakan}

Tabel 1 merangkum karakteristik semua studi yang disertakan. Penelitian yang diambil merupakan kohort retrospektif dan cross sectional. Studi yang disertakan dilakukan di berbagai negara, 2 dari Amerika Serikat, 2 dari Cina, 1 dari Italia, 1 dari Iran, dan 1 dari India. Istilah "COVID-19 berat" didefinisikan secara berbeda di setiap penelitian yang disertakan. Kriteria klinis untuk COVID-19 berat adalah masuk ICU dan penggunaan ventilator. Setiap studi diterbitkan sebagai manuskrip lengkap. 
Tabel 1. Tabel analisis PICO

\begin{tabular}{|c|c|c|c|c|c|c|c|c|}
\hline \multirow[b]{2}{*}{ Penulis (tahun) } & \multirow[b]{2}{*}{ Negara } & \multirow[b]{2}{*}{ Tipe Studi } & \multicolumn{2}{|c|}{ Jumlah Total } & \multirow[b]{2}{*}{ Population } & \multirow[b]{2}{*}{ Intervention } & \multirow[b]{2}{*}{ Comparison } & \multirow[b]{2}{*}{ Outcome } \\
\hline & & & $\begin{array}{c}\text { Dengan } \\
\text { Gejala GI }\end{array}$ & $\begin{array}{c}\text { Tanpa } \\
\text { Gejala GI }\end{array}$ & & & & \\
\hline $\begin{array}{l}\text { (Nobel et al., } \\
2020)\end{array}$ & USA & $\begin{array}{l}\text { Kohort } \\
\text { retrospektif }\end{array}$ & 97 & 181 & $\begin{array}{l}\text { Pasien terkonfirmasi } \\
\text { COV-19 }\end{array}$ & $\begin{array}{l}\text { Pasien usia } \geq 18 \text { tahun } \\
\text { dengan gejala GI }\end{array}$ & $\begin{array}{l}\text { Pasien usia } \geq 18 \\
\text { tahun tanpa } \\
\text { gejala GI }\end{array}$ & $\begin{array}{l}\text { Keperluan perawatan } \\
\text { ICU termasuk ventilasi } \\
\text { mekanis dan kematian } \\
\text { di rumah sakit }\end{array}$ \\
\hline $\begin{array}{l}\text { (Buscarini et } \\
\text { al., 2020) }\end{array}$ & Italy & $\begin{array}{l}\text { Kohort } \\
\text { Retrospektif }\end{array}$ & 42 & 369 & $\begin{array}{l}\text { Pasien terkonfirmasi } \\
\text { COVID-19 }\end{array}$ & $\begin{array}{l}\text { Kelompok dengan } \\
\text { gejala GI }\end{array}$ & $\begin{array}{l}\text { Kelompok tanpa } \\
\text { gejala GI }\end{array}$ & $\begin{array}{l}\text { Perawatan ICU dan } \\
\text { kematian }\end{array}$ \\
\hline $\begin{array}{l}\text { (Ramachandran } \\
\text { et al., 2020) }\end{array}$ & USA & $\begin{array}{l}\text { Kohort } \\
\text { Retrospektif }\end{array}$ & 31 & 119 & $\begin{array}{l}\text { Pasien terkonfirmasi } \\
\text { COVID-19 }\end{array}$ & $\begin{array}{l}\text { Pasien usia } \geq 18 \\
\text { tahun, tidak sedang } \\
\text { hamil, dengan gejala } \\
\text { GI }\end{array}$ & $\begin{array}{l}\text { Pasien usia } \geq 18 \\
\text { tahun, tidak } \\
\text { sedang hamil, } \\
\text { tanpa gejala GI }\end{array}$ & $\begin{array}{l}\text { Keperluan ventilasi } \\
\text { mekanis dan kematian }\end{array}$ \\
\hline $\begin{array}{l}\text { (Cao et al., } \\
2020)\end{array}$ & China & Cross sectional & 63 & 94 & $\begin{array}{l}\text { Pasien terkonfirmasi } \\
\text { COVID-19 }\end{array}$ & $\begin{array}{l}\text { Pasien COVID-19 } \\
\text { dengan gejala GI }\end{array}$ & $\begin{array}{l}\text { Pasien COVID- } \\
19 \text { tanpa gejala } \\
\text { GI }\end{array}$ & $\begin{array}{l}\text { Kasus berat, } \\
\text { penggunaan } \\
\text { kortikosteroid, dan } \\
\text { durasi perawatan di RS }\end{array}$ \\
\hline $\begin{array}{l}\text { (Leipan et al., } \\
\text { 2020) }\end{array}$ & China & Cross sectional & 101 & 103 & $\begin{array}{l}\text { Pasien terkonfirmasi } \\
\text { COVID-19 }\end{array}$ & $\begin{array}{l}\text { Pasien COVID-19 } \\
\text { dengan gejala GI }\end{array}$ & $\begin{array}{l}\text { Pasien COVID- } \\
19 \text { tanpa gejala } \\
\text { GI }\end{array}$ & $\begin{array}{l}\text { Lama perawatan di RS, } \\
\text { kematian, jumlah } \\
\text { perawatan ICU }\end{array}$ \\
\hline $\begin{array}{l}\text { (Tharwat et al, } \\
\text { 2020) }\end{array}$ & Iraq & $\begin{array}{l}\text { Kohort } \\
\text { Retrospektif }\end{array}$ & 78 & 62 & $\begin{array}{l}\text { Pasien terkonfirmasi } \\
\text { COVID-19 }\end{array}$ & $\begin{array}{l}\text { Pasien COVID-19 } \\
\text { dengan gejala GI }\end{array}$ & $\begin{array}{l}\text { Pasien COVID- } \\
19 \text { tanpa gejala } \\
\text { GI }\end{array}$ & $\begin{array}{l}\text { Perawatan ICU dan } \\
\text { kematian }\end{array}$ \\
\hline $\begin{array}{l}\text { (Uday C et al, } \\
\text { 2020) }\end{array}$ & India & $\begin{array}{l}\text { Kohort } \\
\text { Retrospektif }\end{array}$ & 26 & 226 & $\begin{array}{l}\text { Pasien terkonfirmasi } \\
\text { COVID-19 }\end{array}$ & $\begin{array}{l}\text { Pasien COVID-19 } \\
\text { dengan gejala GI }\end{array}$ & $\begin{array}{l}\text { Pasien COVID- } \\
19 \text { tanpa gejala } \\
\text { GI }\end{array}$ & $\begin{array}{l}\text { Perawatan ICU dan } \\
\text { kematian }\end{array}$ \\
\hline
\end{tabular}


Tabel 2. Penilaian kualitas penelitian dengan Quality Assessment Tools for Observational Cohort dan Cross-Sectional Studies

\begin{tabular}{|c|c|c|c|c|c|c|c|}
\hline \multirow[b]{2}{*}{ Ceklis Pertanyaan } & \multicolumn{5}{|c|}{ Publikasi (Penulis,Tahun) } & \multirow[b]{2}{*}{$\begin{array}{l}\text { (Tharwat et } \\
\text { al., 2020) }\end{array}$} & \multirow[b]{2}{*}{$\begin{array}{l}\text { (Uday et } \\
\text { al., 2020) }\end{array}$} \\
\hline & $\begin{array}{l}\text { (Nobel et } \\
\text { al., 2020) }\end{array}$ & $\begin{array}{l}\text { (Buscarini et al., } \\
\text { 2020) }\end{array}$ & $\begin{array}{l}\text { (Ramachandran et } \\
\text { al., 2020) }\end{array}$ & $\begin{array}{l}\text { (Cao et al., } \\
2020)\end{array}$ & $\begin{array}{l}\text { (Leipan et } \\
\text { al., 2020) }\end{array}$ & & \\
\hline $\begin{array}{l}\text { Apakah pertanyaan atau tujuan penelitian } \\
\text { dalam artikel dinyatakan dengan jelas? }\end{array}$ & 1 & 1 & 1 & 1 & 1 & 1 & 1 \\
\hline $\begin{array}{l}\text { Apakah populasi penelitian didefinisikan } \\
\text { dengan jelas? }\end{array}$ & 1 & 1 & 1 & 1 & 1 & 1 & 1 \\
\hline $\begin{array}{l}\text { Apakah tingkat partisipasi yang memenuhi } \\
\text { persyaratan minimal } 50 \% \text { ? }\end{array}$ & 1 & 1 & 1 & 1 & 1 & 1 & 1 \\
\hline $\begin{array}{l}\text { Apakah semua subjek dipilih dari populasi } \\
\text { yang sama atau serupa (termasuk periode } \\
\text { waktu yang sama)? Apakah kriteria inklusi } \\
\text { dan eksklusi untuk berada dalam penelitian } \\
\text { ditentukan sebelumnya dan diterapkan } \\
\text { secara seragam kepada semua peserta? }\end{array}$ & 1 & 1 & 1 & 1 & 1 & 1 & 1 \\
\hline $\begin{array}{l}\text { Apakah terdapat justifikasi ukuran sampel, } \\
\text { deskripsi kekuatan, atau perkiraan variasi } \\
\text { dan efek? }\end{array}$ & 1 & 1 & 1 & 1 & 1 & 1 & 1 \\
\hline $\begin{array}{l}\text { Untuk analisis dalam artikel, apakah } \\
\text { eksposur diukur sebelum hasilnya diukur? }\end{array}$ & 0 & 0 & 0 & 0 & 0 & 0 & 0 \\
\hline $\begin{array}{l}\text { Apakah jangka waktunya cukup sehingga } \\
\text { orang dapat mengharapkan untuk melihat } \\
\text { hubungan antara eksposur dan hasilnya jika } \\
\text { ada? }\end{array}$ & 1 & 1 & 1 & 0 & 1 & 1 & 1 \\
\hline
\end{tabular}


Untuk eksposur yang dapat bervarias dalam jumlah atau tingkat, apakah

penelitian memeriksa perbedaan tingkat paparan dalam kaitannya dengan hasil (misalnya, kategori paparan, atau eksposur diukur sebagai variabel kontinu)?

Apakah ukuran paparan (variabel independen) didefinisikan dengan jelas, valid, andal dan diterapkan secara konsisten pada semua peserta studi?

Apakah paparan dinilai lebih dari sekali dari waktu ke waktu?

Apakah ukuran hasil (variabel dependen) didefinisikan dengan jelas, valid, andal, dan diterapkan secara konsisten pada semua peserta studi?

Apakah penilai hasil tidak mengetahui status keterpaparan peserta?

Apakah loss to follow-up setelah baseline $20 \%$ atau kurang?

Apakah variabel pengganggu potensial utama diukur dan disesuaikan secara statistik dampaknya pada hubungan antara paparan dan hasil? 
Enam penelitian dengan sampel 1388 pasien COVID-19 melaporkan tingkat keparahan infeksi COVID-19 pada pasien dengan dan tanpa gejala gastrointestinal (Gambar 2A). Menurut hasil analisis, belum dapat disimpulkan mengenai korelasi yang signifikan antara peningkatan keparahan COVID-19 dan adanya gejala gastrointestinal (adjusted OR 0,77; 95 persen CI 0,35-1,70; $\mathrm{I} 2=0,73 ; \mathrm{p}=0,52$ )
Sementara itu, sebanyak 1258 pasien COVID-19 dilaporkan dalam enam penelitian terkait kematian akibat infeksi COVID-19 pada pasien dengan dan tanpa gejala gastrointestinal (Gambar 2B). Pada analisis data belum dapat disimpulkan korelasi yang signifikan antara kematian pasien COVID-19 dengan adanya gejala gastrointestinal (adjusted OR 0,87; 95 persen CI 0,34-2,21; $\mathrm{I} 2=0,63$;

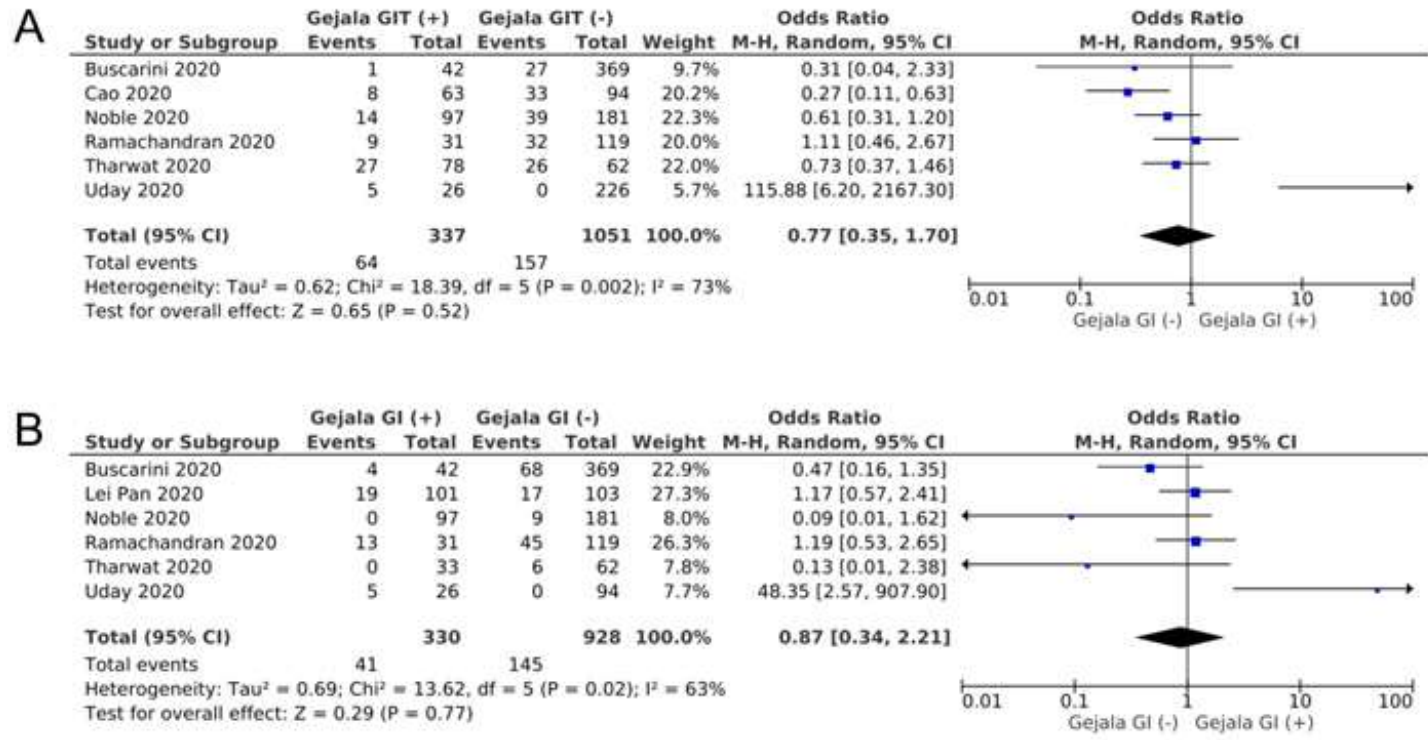

Gambar 2. Forest plot gejala gastrointestinal sebagai faktor prognostik keparahan (A) dan kematian (B) pada Pasien COVID-19
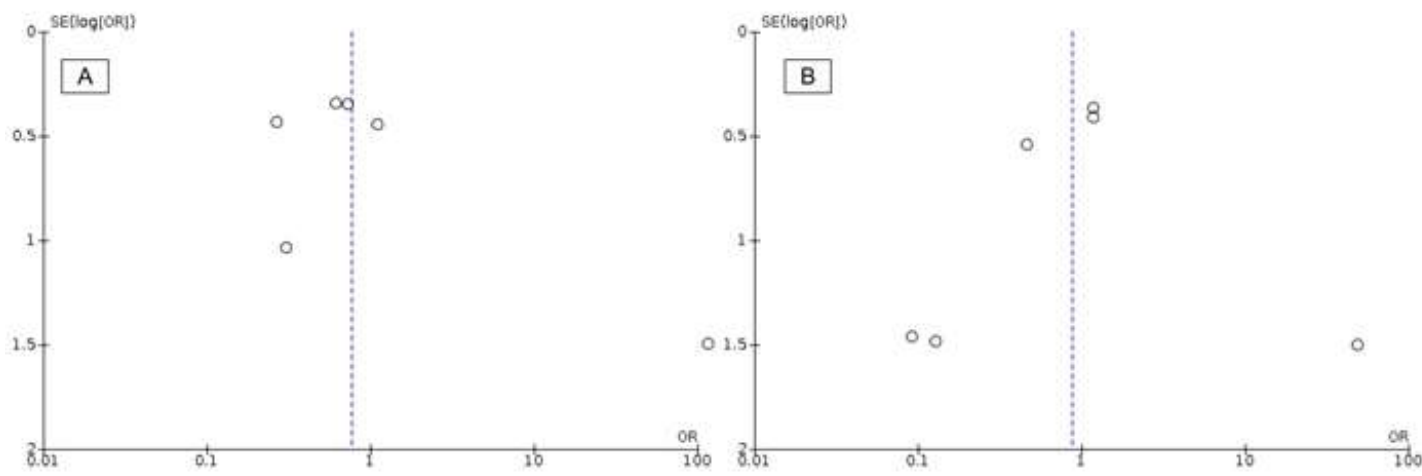

Gambar 3. Funnel plot gejala gastrointestinal sebagai faktor prognostik keparahan (A) dan kematian (B) pada Pasien COVID-19 
Funnel plot pada gambar 3A mengenai gejala gastrointestinal sebagai faktor prognostik keparahan menunjukkan segitiga yang tidak simetris. Hal tersebut menandakan adanya publication bias. Hasil funnel plot pada gambar 3B mengenai gejala gastrointestinal sebagai faktor prognostik kematian menunjukkan hasil simetris yang berarti tidak ditemukan adanya publication bias.

\section{PEMBAHASAN}

Hasil dari analisis data menunjukkan bahwa gejala gastrointestinal belum dapat disimpulkan berhubungan secara signifikan dengan keparahan (aOR 0,77; 95 persen CI $0,35-1,70 ; \quad \mathrm{I} 2=0,73 ; \mathrm{p}=0,52)$ dan kematian pasien COVID-19 (aOR 0,87; 95 persen CI $0,34-2,21 ; \mathrm{I} 2=0,63 ; \mathrm{p}=0,77$ ), sesuai dengan mayoritas sumber literatur yang digunakan. Enam dari total tujuh jurnal dalam studi ini menunjukkan hubungan yang tidak signifikan $(7,8,9,10,11,12)$. Hal ini disebabkan karena sebagian besar studi tidak menjelaskan apakah pasien yang mengalami gejala gastrointestinal juga mengalami gejala lain, seperti gejala respirasi. Selain itu, mayoritas studi juga tidak membedakan antara pasien yang mengalami gejala gastrointestinal (GI) saja dengan yang mengalami gejala GI disertai gejala respirasi, yang dapat mempengaruhi hasil studi. Penelitian menunjukkan bahwa pasien dengan gabungan gejala respirasi dan GI cenderung mengalami gejala yang lebih berat serta kematian yang lebih tinggi dibandingkan dengan pasien yang hanya mengalami gejala GI ${ }^{11}$.

Selain itu, sebagian besar penelitian yang termasuk dalam tinjauan ini tidak menyebutkan adanya faktor resiko atau penyakit penyerta yang berkontribusi terhadap peningkatan keparahan dan kematian pasien COVID-19. Kondisi tertentu seperti diabetes melitus, obesitas, dan penyakit jantung telah dikaitkan dengan peningkatan keparahan dan kematian pada pasien COVID-19 ${ }^{12}$.
ARDS adalah penyebab utama kematian di antara pasien dengan COVID-19. Sebuah studi oleh Hasan et al. (2020) mengungkapkan bahwa perkiraan kematian gabungan untuk ARDS pada pasien COVID19 adalah 39\% (95\% CI: 23-56\%). Bahkan di China, ARDS bertanggung jawab atas 69\% kematian pasien COVID-19 (12).

Virus SARS-CoV-2 sendiri berpotensi mengganggu flora usus, sehingga menyebabkan masalah pencernaan. Usus adalah organ imunologis terbesar tubuh, melalui sistem kekebalan mukosa umum, perubahan komposisi dan fungsi flora saluran pencernaan diketahui dapat mempengaruhi saluran pernapasan dan sebaliknya, penyakit flora saluran pernapasan juga berdampak pada saluran pencernaan melalui regulasi imunologi. Fenomena ini disebut sebagai "gutlung axis" dan mungkin dapat membantu menjelaskan mengapa pasien dengan pneumonia COVID-19 sering juga mengalami masalah saluran cerna ${ }^{10}$.

Pada penelitian terdahulu belum terdapat penelitian yang membahas gejala gastrointestinal sebagai faktor prediktif keparahan dan kematian pasien COVID-19 menggunakan data global dari beberapa pusat rumah sakit di berbagai negara. Sehingga penelitian ini menjadi penelitian awalan yang membahas topik tersebut. Hasil penelitian ini telah memvalidasi temuan penelitian lain oleh Hayashi et al (2021) yang mengevaluasi hubungan antara gejala GI dan tingkat keparahan COVID-19. Penelitian tersebut juga menemukan hasil yang sama, bahwa tidak terdapat perbedaan yang signifikan pada tingkat keparahan pasien COVID-19 dengan gejala GI dibandingkan pasien tanpa gejala GI 13

Keterbatasan penelitian ini adalah jumlah populasi pasien yang relatif sedikit, yaitu masing-masing 1388 dan 1588 pasien untuk tingkat keparahan dan kematian. hal ini disebabkan karena sebagian besar penelitian tidak memasukkan anoreksia, yang merupakan 
gejala yang paling sering ditemukan, sebagai gejala GI. Anoreksia dipertimbangkan sebagai gejala yang tidak spesifik di mana anoreksia dapat disebabkan oleh infeksi umum atau reaksi inflamasi lainnya ${ }^{7}$. Sehingga perlu dilakukan penelitian lanjutan dengan populasi yang lebih besar agar hasil yang diperoleh lebih representatif. Sebagian besar literatur juga menggunakan desain penelitian retrospektif yang bergantung pada keakuratan dokumentasi klinis yang dapat menyebabkan bias recall. Literatur lain juga mempertimbangkan infeksi manusia ke manusia melalui transmisi fekal oral yang dapat menetap setelah resolusi gejala pernapasan ${ }^{14}$. Sehingga penelitian selanjutnya perlu menilai peran pemeriksaan feses sebagai tes diagnostik dan prognostik pada pasien COVID-19. Dengan demikian, hubungan antara prognosis dan gejala pencernaan masih harus diselidiki dengan data yang lebih besar di seluruh dunia.

Mengingat bahwa gejala pencernaan mungkin menjadi salah satu aspek yang muncul dari COVID-19, maka tenaga kesehatan perlu waspada. Karena dalam beberapa keadaan, gejala tersebut dapat terjadi sebelum gejala pernapasan atau mungkin merupakan satu-satunya gejala yang muncul dari COVID-19. Sehingga tetap harus berhatihati ketika pasien datang dengan demam dan masalah perut, bahkan jika tidak ada gejala pernapasan. Pemahaman ini dapat membantu dalam deteksi dini COVID-19, waktu perawatan yang lebih singkat, karantina lebih awal, dan pencegahan penularan yang lebih luas.

\section{KESIMPULAN}

Berdasarkan analisis data yang dilakukan, belum dapat disimpulkan bahwa gejala GI berpengaruh terhadap keparahan dan kematian pasien COVID-19. Selain itu, belum terdapat bukti yang cukup mengenai keterkaitan gejala GI dengan keparahan dan kematian pada COVID-19. Kesimpulan yang didapat bahwa masalah GI sering terjadi pada kasus COVID-19. Pasien COVID-19 dengan gejala GI cenderung mengalami kondisi penyakit yang ringan, yang dapat menyebabkan tertundanya pasien datang ke rumah sakit dan diagnosis pun tertunda. Tes COVID-19 harus dipertimbangkan pada pasien dengan demam disertai gejala gastrointestinal dalam konteks memperhatikan gejala GI untuk diagnosis dini dan memperbaiki prognosis. Fakta bahwa SARSCoV-2 telah terdeteksi pada feses pasien dan sistem pencernaan, kita harus berhati-hati dan mempertimbangkan kemungkinan jalur penularan fekal oral ${ }^{14,15}$. Penelitian lebih lanjut diperlukan untuk mengevaluasi efek gejala GI pada outcome pasien COVID-19.

\section{UCAPAN TERIMA KASIH}

Alhamdulillah, puji syukur kepada Allah Sang Maha Pengatur skenario terbaik dalam hidup kami. Terimaksih kami ucapkan kepada Prof. Ari Natalia Probandari, dr., M.P.H., Ph.D., dr. Vitri Widyaningsih, M.S., Ph.D., dan dr. Ratih Puspit Febrinasari, M.Sc. yang telah memberikan kami bimbingan serta masukan dalam penyusunan karya ini. Juga terimakasih kami ucapkan kepada orang tua kami yang tidak pernah berhenti mendukung kami, mendoakan kami siang dan malam dalam setiap detik kehidupan. Kami juga berterimakasih kepada database (PubMed, Science Direct dan Springer Link) yang telah menyediakan informasi dan data pada jurnal ini. Semoga tulisan ini dapat memberikan manfaat seluas-luasnya.

\section{DAFTAR PUSTAKA}

1. Ge H, Wang X, Yuan X, Xiao G, Wang C, Deng $\mathrm{T}$, et al. The epidemiology and clinical information about COVID-19. Eur J Clin Microbiol Infect Dis. 2020;39(6):1011-9.

2. WHO. COVID-19 Weekly Epidemiological Update 41 [Internet]. World Health Organization. 2021. p. 1-3. Available from: https://www.who.int/docs/defaultsource/coronaviruse/situation- 
reports/weekly_epidemiological_update_22. pdf

3. WHO. Coronavirus disease (COVID-19) [Internet]. World Health Organization. 2021. Available from: https://www.who.int/healthtopics/coronavirus\#tab=tab_3

4. Zaim S, Chong JH, Sankaranarayanan V, Harky A. COVID-19 and multi-organ response. Curr Probl Cardiol. 2020;100618.

5. Deidda S, Tora L, Firinu D, Del Giacco S, Campagna M, Meloni F, et al. Gastrointestinal coronavirus disease 2019: epidemiology, clinical features, pathogenesis, prevention, and management. Expert Rev Gastroenterol Hepatol. 2020;110.

6. Uday G, Ghoshal U, Mathur A, Singh RK, Nath A, Garg A, et al. The Spectrum of Gastrointestinal Symptoms in Patients With Coronavirus Disease-19: Predictors, Relationship With Disease Severity, and Outcome. Clin Transl Gastroenterol. 2020;11(12).

7. Ramachandran $\mathrm{P}$, Onukogu I, Ghanta S, Gajendran M, Perisetti A, Goyal H, et al. Gastrointestinal symptoms and outcomes in hospitalized coronavirus disease 2019 patients. Dig Dis. 2020;38(5):373-9.

8. Cao C, Chen M, He L, Xie J, Chen X. Clinical features and outcomes of COVID19 patients with gastrointestinal symptoms. Crit Care. 2020;24(1):1-3.

9. Buscarini E, Manfredi G, Brambilla G, Menozzi F, Londoni C, Alicante S, et al. GI symptoms as early signs of COVID-19 in hospitalised Italian patients. Gut. 2020;69(8):1547-8.

10. Pan L, Mu M, Yang P, Sun Y, Wang R, Yan $\mathrm{J}$, et al. Clinical characteristics of COVID19 patients with digestive symptoms in Hubei, China: a descriptive, cross-sectional, multicenter study. Am J Gastroenterol. 2020;115.

11. Sulaiman T, Algharawi AA, Idrees $M$, Alzaidy RH, Faris K, Cullingford G, et al. The prevalence of gastrointestinal symptoms among patients with COVID- 19 and the effect on the severity of the disease. JGH Open. 2020;4(6):1162-6.

12. Hasan SS, Capstick T, Ahmed R, Kow CS, Mazhar F, Merchant HA, et al. Mortality in COVID-19 patients with acute respiratory distress syndrome and corticosteroids use: a systematic review and meta-analysis. Expert Rev Respir Med. 2020;14(11):1149-63.

13. Hayashi Y, Wagatsuma $K$, Nojima M, Yamakawa T, Ichimiya T, Yokoyama Y, et al. The characteristics of gastrointestinal symptoms in patients with severe COVID19: a systematic review and meta-analysis. J Gastroenterol. 2021;1-12.

14. Perisetti A, Gajendran M, Boregowda U, Bansal P, Goyal H. COVID- 19 and gastrointestinal endoscopies: current insights and emergent strategies. Dig Endosc. 2020;32(5):715-22.

15. Parasa S, Desai M, Chandrasekar VT, Patel HK, Kennedy KF, Roesch T, et al. Prevalence of gastrointestinal symptoms and fecal viral shedding in patients with coronavirus disease 2019: a systematic review and meta-analysis. JAMA Netw open. 2020;3(6):e2011335-e2011335. 